\title{
Team-Based Learning: a randomized clinical trial in undergraduate nursing
}

\author{
Aprendizagem baseada em equipes: um ensaio clínico randomizado na graduação em enfermagem \\ Aprendizaje Basado en Equipos: un ensayo clínico randomizado en la graduación en enfermería
}

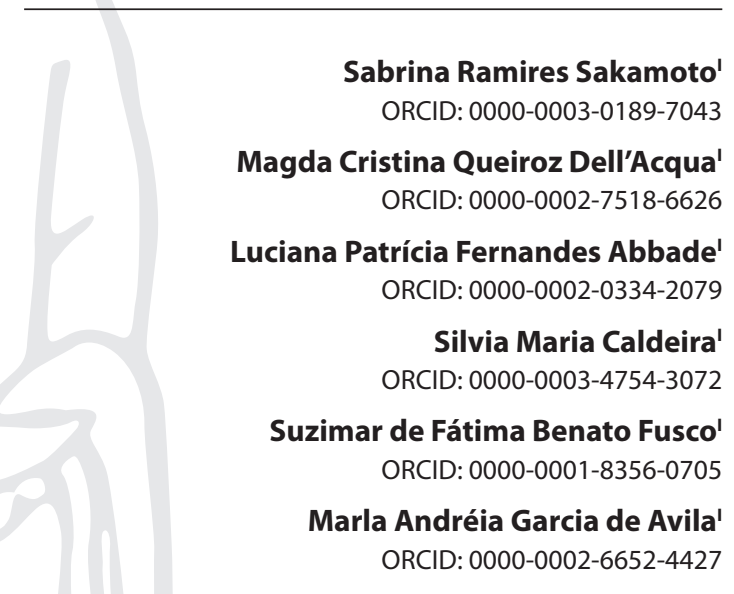

'Universidade Estadual Paulista. Botucatu, São Paulo, Brazil.

How to cite this article: Sakamoto SR, Dell'Acqua MCQ, Abbade LPF, Caldeira SM, Fusco SFB, Avila MAG. Team-Based Learning: a randomized clinical trial in undergraduate nursing.

Rev Bras Enferm. 2020;73(2):e20180621. doi: http://dx.doi.org/10.1590/0034-7167-2018-0621

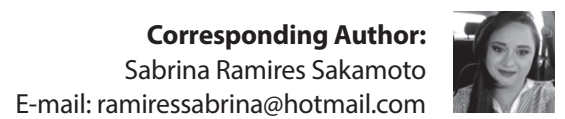

EDITOR IN CHIEF: Antonio José de Almeida Filho ASSOCIATE EDITOR: Hugo Fernandes

Submission: 09-20-2018

Approval: 03-24-2019

\begin{abstract}
Objectives: To compare the knowledge on surgical safety through the team-based learning methodology and lecture classes for undergraduate Nursing students, and evaluate the learning satisfaction with team-based learning. Methods: Randomized, controlled, parallel, two-arm, unblinded clinical trial developed in the Faculty of Medicine of a public university in Botucatu, Brazil. The groups included 14 students for team-based learning and 11 students for lecture classes. Results: Students' apprehension of knowledge in the teambased learning group was significantly higher compared to the control group $(p<0.002)$ by considering the pre-test results. After 30 days, there was no significant difference between groups. The experience with the methodology was considered positive among students. Conclusions: Team-based learning is an important pedagogic tool available and has proven effective in education and learning with students playing the role of protagonists. Descriptors: Validation Studies; Nursing; Randomized Controlled Clinical Trial; Higher Education; Patient Safety.
\end{abstract}

\section{RESUMO}

Objetivos: Comparar a apreensão do conhecimento em segurança cirúrgica pela metodologia da aprendizagem baseada em equipes e aula expositiva dialogada para alunos de graduação em enfermagem e avaliar a satisfação do aprendizado na aprendizagem baseada em equipes. Métodos: Ensaio clínico randomizado, controlado, paralelo, com dois braços, sem cegamento, desenvolvido em uma universidade pública paulista. Os grupos foram compostos por 14 alunos para aprendizagem baseada em equipes e 11 alunos para aula expositiva dialogada. Resultados: A apreensão de conhecimento dos alunos do grupo aprendizagem baseada em equipes foi significativamente maior em comparação com o grupo controle $(p<0,002)$ considerados os resultados do pré-teste. Após os 30 dias, não houve diferença significativa entre os grupos. A experiência com a metodologia foi considerada positiva entre os alunos. Conclusões: A aprendizagem baseada em equipes é uma importante ferramenta pedagógica disponível e mostra-se eficaz no processo de ensino-aprendizagem tendo o aluno como seu protagonista.

Descritores: Estudos de Validação; Enfermagem; Ensaio Clínico Controlado Aleatório; Educação Superior; Segurança do Paciente.

\section{RESUMEN}

Objetivos: Comparar la aprehensión del conocimiento en seguridad quirúrgica por la metodología del aprendizaje basada en equipos y clase expositiva para alumnos de graduación en enfermería y evaluar la satisfacción del aprendizaje en el aprendizaje basado en equipos. Métodos: Ensayo clínico aleatorizado, controlado, paralelo, con dos brazos, no ciego, desarrollado en una universidad pública ubicada en Botucatu, Brasil. Los grupos fueron compuestos por 14 alumnos para el aprendizaje basado en equipos y 11 alumnos para clase expositiva. Resultados: La aprehensión del conocimiento de los alumnos del grupo aprendizaje basado en equipos fue significativamente mayor comparado al grupo control $(p<0,002)$ considerados los resultados del pre-test. Después de los 30 días, no hubo diferencia significativa entre los grupos. La experiencia con la metodología fue considerada positiva entre los alumnos. Conclusiones: El aprendizaje basado en equipos es una importante herramienta pedagógica disponible y se muestra eficaz en el proceso de enseñanza-aprendizaje teniendo al alumno como su protagonista.

Descriptores: Estudios de Validación; Enfermería; Ensayo Clínico Controlado Aleatorizado; Educación Superior; Seguridad del Paciente. 


\section{INTRODUCTION}

Active learning methodologies are defined as an educational concept that encourages critical-reflexive teaching-learning processes ${ }^{(1)}$ in which students become protagonists and teachers assume the role of mediators/facilitators ${ }^{(2)}$. Such methodologies require the following from students: active participation in the teaching-learning process, search for knowledge, appropriation of knowledge, and critical reflection on what was learned to later perform actions and transform the reality in which they live ${ }^{(1)}$. The teacher's role is to encourage students to verbalize their ideas, help them become aware of their own learning process, and relate their previous experiences with study situations. A critical construction of knowledge is closely associated with questioning, whether to understand students'thinking or promote conceptual learning ${ }^{(3)}$.

The Team-Based Learning (TBL) developed by Larry K. Michaelsen at the University of Oklahoma in 1970 $0^{(4-5)}$, is based on teamwork, in-depth reasoning and critical thinking. The method allows that students are stimulated to develop, process and discuss, and as a result, increase their intellectual ability on a particular subject ${ }^{(6)}$. It also works as an instructional strategy in small groups that can be performed through sequential activities ${ }^{(7-8)}$ of preparation (individual pre-study), readiness assurance (individual test, team test and immediate feedback from the teacher) and application of the concept (problem situation of clinical practice) (5,9). Activities improve interaction among group members, who are able to manage differences and work as a team ${ }^{(10)}$.

The performance of TBL includes the following steps: individual preparation (pre-class), readiness assurance (class), application of concepts (class). In the individual preparation, students study the material sent by the teacher according to the proposed theme.

The readiness assurance includes the application of a verification test completed individually by students without consultation. The test consists of 10 to 20 multiple choice questions that allow a 'guess' in the right alternative, or in more than one. In each question, the 'guess' is worth four points, and students can put all four 'guesses' in a single alternative, or divide them in the way they prefer among other alternatives, as long as the total sum is four points ${ }^{(11-12)}$. Following, the same activities are carried out and discussed in teams with the intention of reaching a consensus. After discussing the answers with the teacher, the method allows the reassessment of the answer of some question by making an appeal based on relevant published material and grounding the argument with theory ${ }^{(11-12)}$.

In the step of application of concepts, all teams solve the same problem, which brings students closer to the clinical practice, where their answers will be reached only through critical thinking and discussion with teammates. In the end, teams should show their response to the group simultaneously ${ }^{(11-12)}$.

Finally, the peer evaluation is performed for students' selfevaluation and for the evaluation of their peers, which demonstrates the responsibility of each one in the teaching-learning process. This process is one of the most important pedagogical tools available and, if well used, becomes one of the central components of the teaching-learning process $\mathrm{s}^{(5,11-12)}$.

The learning environment in small groups, when compared to the traditional modality of competitive and individualistic learning, is beneficial for students by bringing greater sense of accomplishment, use and learning of deep reasoning and critical thinking ${ }^{(13)}$. In addition, it may contribute to more effective clinical practices such as improved communication, collaboration, and teamwork ${ }^{(8,13)}$.

The international literature shows positive results of TBL in undergraduate Nursing teaching with students' satisfaction in team learning ${ }^{(8)}$ and improvement of problem-solving skills, clinical performance, and knowledge ${ }^{(14)}$. At the postgraduate level, it collaborates for the early acquisition of critical thinking, development of communication skills, teamwork and knowledge of specialized clinical practice ${ }^{(15)}$. A recent meta-analysis with 17 intervention studies including postgraduate students showed significant $(p<0.001)$ effects of TBL through analysis of pre-tests, post-tests, and final scores on the results of knowledge of contents. Students also reported that TBL is interesting and allows deeper understanding of the content ${ }^{(16)}$.

There are few national studies, especially in the area of health and particularly in the area of Nursing, that demonstrate or evaluate the TBL method, and they have low level of evidence. Two national studies describe the methodology and are important for teachers who wish to delve deeper into the subject ${ }^{(5,9)}$. Other studies in the area of Accounting Sciences ${ }^{(17)}$, Pharmacy ${ }^{(18)}$, Medicine ${ }^{(16)}$ and Nursing ${ }^{(11-12)}$ also report positive aspects of TBL in undergraduate studies regarding satisfaction with the method for learning. In a collective health discipline of a postgraduate course ${ }^{(19)}$, the implementation of TBL methodology was very satisfactory, although students have reported difficulty with the request of previously studying the lesson content.

\section{OBJECTIVES}

To compare the apprehension of knowledge on surgical safety through the TBL method with a lecture class for undergraduate nursing students and to evaluate learning satisfaction with the TBL methodology.

\section{METHODS}

\section{Ethical aspects}

The study was registered in the Brazilian Registry of Clinical Trials (number: RBR-4F32XY) and approved by the Research Ethics Committee of the Faculty of Medicine of Botucatu.

\section{Design, place of study and period}

Randomized, controlled, parallel, two-arm, non-blinded clinical trial.

The study was developed in the first half of 2017 at a public university in the state of São Paulo, Brazil, in the Surgical Center Nursing discipline of the undergraduate Nursing course.

\section{Population}

The undergraduate Nursing course offers 30 places per year in a fulltime course, includes semester credit/disciplines and the period for curricular completion is between four and six years. 
The Surgical Center Nursing discipline is offered in the first semester of the third year of the undergraduate Nursing course, under coordination of two teachers with a workload of 195 hours distributed in theoretical and practical activities.

All students were informed both verbally and in writing about the study and signed the Informed Consent form with the guarantee that scores obtained in the tests would not be considered as evaluation criteria of the academic discipline involved, and that their refusal in the study would not affect their academic activities. We included the 28 students enrolled in the Surgical Center Nursing discipline of the undergraduate Nursing course in the year 2017. Students who were absent on the day of class were excluded.

\section{Study protocol}

The enrollment system distributes students in three groups called A, B and C for the performance of activities. The methodologies used in the course are: lectures, TBL and practical classes.

The non-probabilistic sample included all 28 students regularly enrolled in the Surgical Center Nursing discipline in the year 2017. Recruitment was performed 15 days before the intervention and students who accepted to participate in the study were included.

Randomization occurred by means of a draw within the groups already formed ( $A, B$ and $C$ ) by the university system in order to respect the integration of groups, since this composition was validated by the group. Two groups were then formed: one with 14 students for the experimental intervention (ABE) divided into $A$, $B$ and $C$; and the control group with 14 students (lecture classes).

The theme chosen for the study was 'Surgical Safety', and the Safe Surgery Saves Lives Manual proposed by the World Health Organization was adopted as a theoretical reference ${ }^{(20)}$. The contents addressed in both the lecture class and the TBL were: surgical recommendations and the detailed application of Surgical Safety procedures.

The pedagogical activity proposed for the control group was a lecture class in Power Point ${ }^{\circ}$ slides lasting approximately 120 minutes and taught by a professor of the Surgical Center Nursing discipline. Initially, the teacher asked students in this group to do the pre-intervention individual test. Note that students had not had previous contact with the bibliography addressed. Then, the teacher taught the class and 30 days later, students did a post-intervention test individually.

The TBL method and steps proposed by the literature were used for the intervention group, as follows: a) Pre-class preparation: a content for individual study was made available for students a week in advance. b) Readiness assurance: students performed the pre-intervention test individually and were allocated to groups A, $B$ and $C$ in order to retake the same test and sought a consensus among teammates. Each group received a scratch card to check the correct alternative. Subsequently, a single group was formed to list and clarify doubts and receive the teacher's feedback. c) Application of concepts: students returned to the formation of groups $\mathrm{A}, \mathrm{B}$ and $\mathrm{C}$ with the purpose of applying, reflecting and deepening the contents through resolution of a problem situation, according to Michaelsen's reference of the $4 \mathrm{Ss}^{(21)}$. d) After 30 days, students individually performed a new post-intervention test.e) Peer evaluation: a form with responses in a 4-point Likert scale consisting of self-assessment questions and peer evaluation on the contribution of each member for the success of teamwork. f) Methodology Evaluation:Team-Based Learning Questionnaire proposed by Hartz and modified by the researchers with questions about students' experience and satisfaction with the method.

Students' characterization was performed by means of a questionnaire including identification, age, gender, previous training, current weighted average of university academic record and previous use of active methodologies. The pre- and post-tests were different from each other, contained 10 multiple-choice questions with four response options and a single correct alternative with the objective of analyzing students' knowledge about the subject.

The primary outcome was the apprehension of knowledge after 30 days of class by comparing groups. The secondary outcome was the peer evaluation and evaluation of the methodology performed by students of the TBL group.

For the organization of data, was built a database in Microsoft Excel, from which charts, diagrams and tables were constructed. Descriptive statistics were performed, the frequencies and percentages for qualitative variables were calculated, as well as mean, median, standard deviation and minimum and maximum values for quantitative variables. Initially, a data normality test was performed and the distribution was found to be symmetric. The Student's T test was performed to check the difference between groups with respect to age and the weighted mean. The ANOVA analysis in repeated measures, followed by the Tukey's test for multiple comparisons were performed in order to check if there was statistical difference between the mean of correct answers of the traditional group versus the TBL group by taking into account the pre- and post-test results. In this study, $\mathrm{p}<0.05$ was considered as level of significance. The SAS for Windows version 9.3 was used to perform the analyzes.

\section{RESULTS}

Twenty-five students completed the study. They were divided into two groups, namely: intervention group $(n=14)$ and control group $(n=11)$. Three individuals in the control group were absent on the day of class, representing a loss of $21.4 \%$ in this group. There were no losses in the intervention group. The flowchart of the sample is shown in Figure 1.

The groups were homogeneous in relation to the age group $(p=0,1986)$ and performance in the undergraduate course $(p=0,3883)$ by considering the coefficient of achievement in disciplines, and there was preponderance of female students (96\%). The mean age in the TBL group was 21.8 years (SD \pm 2.2 ) and in the traditional group, it was 20.7 years ( $S D \pm 1.8$ ). The mean performance in the undergraduate course was $7.2(S D \pm 0.9)$ in the TBL group and $7.5(S D \pm 0.9)$ in the traditional group.

The analyzes of pre-test evaluations showed that the TBL group presented more correct answers compared to the group of lecture class with a significant difference $(p<0.002)$. In the post-test, the TBL group also presented more correct answers, but the difference was not significant in relation to the number of correct answers in the control group. When comparing the moments (pre- and post-test) of each group, no difference was 
observed in the TBL group, but was observed in the lecture class group (Table 1). Note that students did not make appeals for reassessment of any question of the tests.

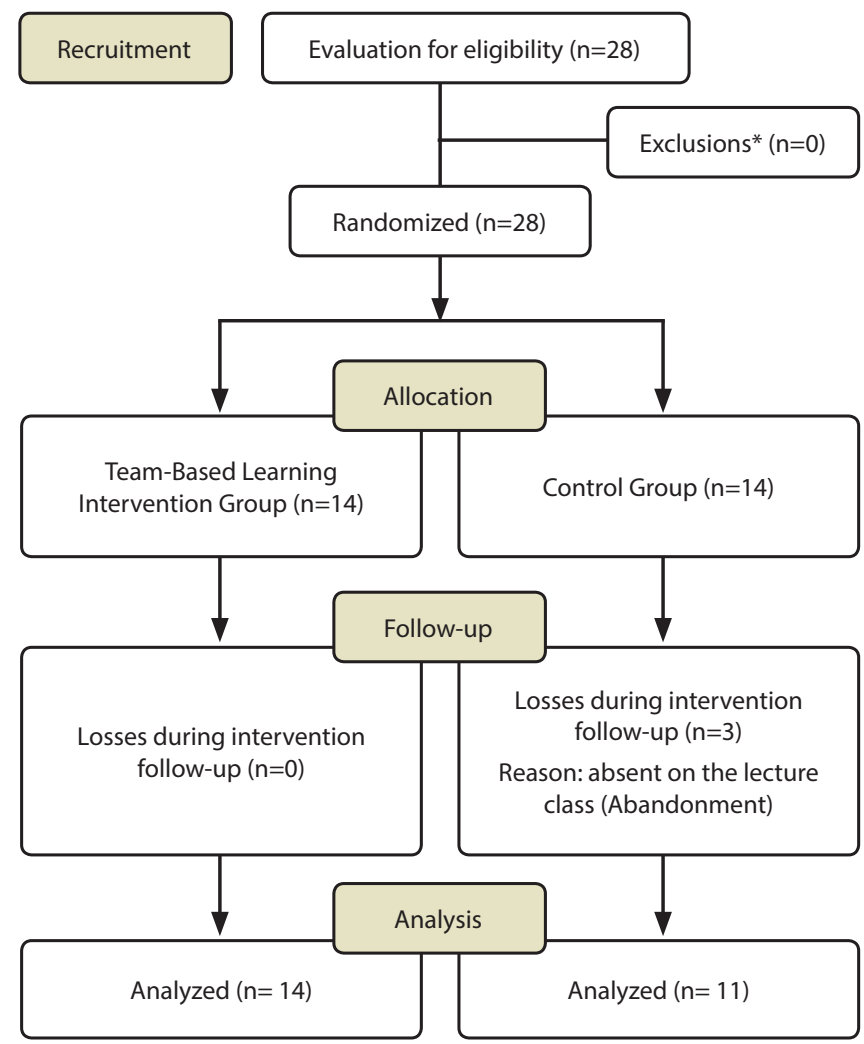

Figure 1 - CONSORT diagram ${ }^{(22)}$ of allocation, follow-up and analysis, Botucatu, São Paulo, Brasil, 2017

Table 1 - Multiple comparisons of group evaluations. Botucatu, São Paulo, 2017

\begin{tabular}{lcccccc}
\hline \multirow{2}{*}{ MOMENT } & \multicolumn{5}{c}{ Multiple Comparisons (0-40 score) } \\
& TBL & \multicolumn{4}{c}{ TRADITIONAL } \\
& MEAN & SD & & MEAN & SD & \\
\hline \multirow{2}{*}{$\begin{array}{l}\text { Pre-test } \\
\text { Post-test }\end{array}$} & 29.4 & \pm 6.4 & Aa & 19.9 & \pm 4.1 & Aa \\
& \multirow{2}{*}{30.6} & \pm 4.0 & Ab & 27.6 & \pm 5.9 & $\mathrm{Ba}$ \\
\hline
\end{tabular}

Note: ${ }^{*}$ Equal capital letters = significant difference between groups $(p<0.002) ;{ }^{*}$ Equal lowercase letters = significant difference within groups $(p<0.002)$

Tabela 2 - Avaliação por pares do grupo Aprendizagem Baseado em Equipes, Botucatu, São Paulo, Brasil, 2017

\begin{tabular}{lcccc}
\hline Variables & $\mathbf{1}$ & $\mathbf{2}$ & $\mathbf{3}$ & $\mathbf{4}$ \\
& $\mathbf{N}(\%)$ & $\mathbf{N}(\%)$ & $\mathbf{N}(\%)$ & $\mathbf{N}(\%)$ \\
\hline Team evaluation & & & & \\
$\begin{array}{l}\text { Participation of all } \\
\text { Balance between participation and listening }\end{array}$ & - & $1(7 \%)$ & $3(21 \%)$ & $10(72 \%)$ \\
Relevant questions & - & - & $3(21 \%)$ & $11(79 \%)$ \\
Sharing of knowledge & - & $1(7 \%)$ & $2(14 \%)$ & $11(79 \%)$ \\
Content understanding & - & - & $2(14 \%)$ & $12(86 \%)$ \\
Self-evaluation & & & & \\
$\begin{array}{l}\text { Prepared for activities } \\
\text { Adequate depth of knowledge }\end{array}$ & - & $1(7 \%)$ & $5(36 \%)$ & $8(57 \%)$ \\
Identification of limitations & - & $1(7 \%)$ & $9(64 \%)$ & $4(29 \%)$ \\
Grounded arguments & - & $2(14 \%)$ & $3(21 \%)$ & $9(64 \%)$ \\
& - & $2(14 \%)$ & $5(36 \%)$ & $7(50 \%)$
\end{tabular}

Note: ${ }^{* 1}$. Never; 2. Sometimes; 3. Often; 4. Always.
Regarding peer evaluation (Table 2), students assessed themselves positively, as did their peers. Also by means of the TBL Questionnaire adapted from Hartz; Schlater ${ }^{(8)}$ (Table 3), the variation of answers reinforced the interest and satisfaction of students by the dynamics of the method.

Table 3 - Adapted TBL questionnaire(6), Botucatu, São Paulo, Brasil, 2017

\begin{tabular}{|c|c|c|c|c|}
\hline Variables & 1 a 3 & (\%) & 4 e 5 & (\%) \\
\hline $\begin{array}{l}\text { 1. I prefer an individual orientation on a } \\
\text { topic, albeit a quick one, than having to } \\
\text { debate it in a group of colleagues. }\end{array}$ & 13 & (92.9) & 1 & (7.1) \\
\hline $\begin{array}{l}\text { 2. The group discussion gave me awareness } \\
\text { on how much I really knew about a } \\
\text { particular work issue. }\end{array}$ & 1 & $(7.1)$ & 13 & (92.9) \\
\hline $\begin{array}{l}\text { 3. I believe I would learn more if I had to } \\
\text { give the teacher a small report on the } \\
\text { subject discussed in the group. }\end{array}$ & 12 & $(85.7)$ & 2 & $(14.3)$ \\
\hline $\begin{array}{l}\text { 4. I believe I have learned a lot from my } \\
\text { colleagues during the group discussions. }\end{array}$ & 1 & (7.1) & 13 & $(92.9)$ \\
\hline $\begin{array}{l}\text { 5. Although it has been useful, I consider } \\
\text { the closure made by the teacher } \\
\text { could be disregarded, since the most } \\
\text { important has already been discussed by } \\
\text { the group. }\end{array}$ & 13 & (92.9) & 1 & (7.1) \\
\hline $\begin{array}{l}\text { 6. I learn more as a group than talking to } \\
\text { the teacher. }\end{array}$ & 8 & $(57.1)$ & 6 & (42.9) \\
\hline $\begin{array}{l}\text { 7. I prefer feedback from a colleague } \\
\text { than from the teacher. }\end{array}$ & 13 & (92.9) & 1 & (7.1) \\
\hline $\begin{array}{l}8 . \text { I believe that small groups discussions } \\
\text { are sufficient to ensure learning about } \\
\text { the topic in question and there is no } \\
\text { need to discuss them in the large group. }\end{array}$ & 11 & (78.6) & 3 & (21.4) \\
\hline $\begin{array}{l}\text { 9. I think if I had to hand in a writing } \\
\text { about the item under debate at the end } \\
\text { of the lesson, I would learn more. }\end{array}$ & 14 & (100.0) & 0 & $(0.0)$ \\
\hline $\begin{array}{l}\text { 10. In general, I can say I enjoyed the } \\
\text { team-based learning approach. }\end{array}$ & 0 & $(0.0)$ & 14 & (100.0) \\
\hline
\end{tabular}

Note: 1.I totally disagree; 2. I disagree; 3 . Neutral; 4. I agree; 5. I totally agree.

\section{DISCUSSION}

Students of the TBL group presented more correct answers to the pre-test questions compared to the lecture class group. These data corroborate the hypothesis of the study in this aspect. The TBL methodology proposes the prior study of the subject that will be taught, and this preparation of students can provide a theoretical basis for the sedimentation of other contents worked in class. This aspect contributes to positive results in this step of the method, i.e., the individual study strengthens an essential characteristic of the method, which is students' responsibility for acquiring their own knowledge, as well as the possibility of better results when seizing knowledge ${ }^{(9,18)}$.

Authors emphasized the significant changes among nursing student teams brought by the TBL methodology, as well as the increase in the quality of learning, clinical reasoning 
ability, professional development and satisfaction with the team's experience $^{(23)}$.

In the problem situation of this study, students had $100 \%$ correct answers. This is in line with a Korean study also conducted with nursing students in which was checked the effectiveness of TBL by means of evaluating the capacity and results of learning in problem solving (knowledge and clinical performance). In the present study, three weeks after the educational interventions, the results on problem solving ability in the TBL group were significantly better than in the control group ${ }^{(14) .}$. The problem situation favors an approximation to the care praxis ${ }^{(11-12)}$.

When evaluating the correct answers after 30 days, there was no differentiation between groups. Nevertheless, the qualitative results of this study indicate the method can be used for the teaching-learning process. Better results are found with greater cohesion between groups. In a Korean study ${ }^{(15)}$ with 74 nursing students, the learning in nursing care with the newborn was evaluated by comparing the simulation with TBL, and no significant difference was found between the groups under study. However, in the study were compared two active methodologies with the teacher acting as a mediator, guiding the teaching-learning process and stimulating students' critical and reflexive thinking through knowledge transfers, and also by monitoring teamwork, which stimulates the expression of ideas, thoughts and knowledge ${ }^{(5,8)}$.

Differently from the statistical results presented here, in other studies was show the superiority of the TBL method. In a study involving 212 students of the anatomy discipline of the physiotherapy course, there were significant results $(p<0.001)$ with use of the TBL throughout the various moments of evaluation performed in the study, such as in relation to teamwork and performance in the written and practical exam, and improvement in practical laboratory analysis, which did not happen with those who received traditional lectures ${ }^{(24)}$.

A quasi-experimental study was conducted at a University of Taiwan with 399 students in four classes of different disciplines, namely: Adult Health Nursing, Maternal and Child Nursing, Community Health Nursing and Medical-Surgical Nursing. There was significant improvement in student learning in the programs applied, including better class involvement $(p<0.001)$ and self-directed learning $(p<0.001)$, which demonstrates the improvement of students'academic performance provided by the methodology ${ }^{(25)}$.

The TBL results were also observed in a national study ${ }^{(17)}$ in the area of Accounting Sciences with 603 students, in which students were followed-up between years 2011 and 2014 when using active methodologies. Numerous benefits from the adoption of the methodology were highlighted, such as increase in grades and decrease in the percentage of absences, which contributed to students' better performance in the studied period.

Our data are in agreement with those from another national study ${ }^{(16)}$, in which was used the TBL method to construct the course completion work, and 49 students were included (27 of the Advertising and Propaganda course and 22 of the Business Administration course). The common point was students' experience regarding the method: everyone liked the approach and felt able to grasp and consolidate the content, and solve problems more effectively. The presence of the teacher as a mediator was considered important, and in this regard, our study corroborates that of Marini(18), in which students indicated preference for guidance and feedback from the teacher than from classmates.

In general, students showed good acceptance of the method and highlighted positive points such as: the importance of students responsibility and autonomy; the encouragement of prior study as a means of guaranteeing independence; the ease of identifying the difficulties and potentialities of students, mainly through group and individual evaluations in the form of 'guess'; and the effectiveness of teamwork, which was pointed as more dynamic and motivating. Students' positive evaluation was also evidenced in a course of Pharmacology ${ }^{(18)}$ and Nursing ${ }^{(11)}$. In a study conducted at a public university in Brazil, the mixed method was used to evaluate TBL from the perspective of 127 students of the perioperative nursing discipline. Among all students, 121 (95.27\%) felt prepared by the individual study and 119 (93.70\%) believed the study encouraged their learning. Regarding the team test, $115(90.55 \%)$ students considered it allowed the understanding of concepts, $111(87.40 \%)$ felt confident about discussing the subject and $100 \%$ reported that feedback from the teacher was essential in the consolidation of concepts. In the step of application of concepts, 122 (96\%) students reported being able to apply the concepts for solving cases and problems, besides being challenged to make analyzes and interpretations. From the analyzes of students'speeches, the authors emphasized the dynamism of the method, the development of critical thinking, and the possibility of student-centered learning and interaction with other colleagues, mainly through shared learning ${ }^{(11)}$.

In the peer analysis performed by the TBL group, students evaluated themselves and their colleagues as well prepared for the activity, which demonstrated the responsibility of each one in the teaching-learning process. This process is one of the most important pedagogical tools available and if well used, becomes one of the central components of the teaching-learning process. Authors recommend the evaluation of students by their individual performance and the outcome of teamwork, in addition to peer evaluation, which increases accountability ${ }^{(5)}$.

The performance of other studies on TBL in the health area with different methodological designs is recommended, as well as studies with numerically enlarged samples.

Diversified themes with complexity can be included for the evaluation beyond closed questions, but with room for apprehension of clinical reasoning and interventions applied to problem solving. The performance of studies aimed at the use of active methodologies and the training of teachers is also important, since these still experience many difficulties in the application of such tools and show some resistance to them ${ }^{(26)}$.

\section{Limitations of the study}

The limitation of this study is the evaluation of the approach of a single content of low complexity with participation of a single class. The tests were performed by researchers and were not validated by a committee of experts.

\section{Contributions to the area of nursing, health or public policy}

The study presents a contribution to undergraduate nursing teaching by using the TBL methodology, which may be an option for teachers who use active methodologies. 


\section{CONCLUSIONS}

The results of this study allowed the following conclusions:

- Undergraduate nursing students' apprehension of knowledge after lecture class versus class with TBL was higher in the TBL group, when considering the pre-intervention results.

- After 30 days, there was no significant difference between the studied groups.

- Students' experience with the methodology was positive. All enjoyed the approach and felt able to apprehend and consolidate content, and solve problems more effectively.

\section{REFERENCES}

1. Aranha MLA. História da educação e da pedagogia. 3a ed. São Paulo: Moderna; 2010.

2. Becker F. O que é construtivismo? Rev Educ AEC. 1992;21(83):7-15.

3. Jófili Z. Piaget, Vygotsky, Freire e a construção do conhecimento na escola [Internet]. Educ Teor Prát. 2002 [cited 2018 Jan 10];2(2):191-208. Available from: https://www.maxwell.vrac.puc-rio.br/7560/7560.PDF

4. Sobral FR, Campos CJG. The use of active methodology in nursing care and teaching in national productions: an integrative review. Rev Esc Enferm USP. 2012;46(1):208-18. doi: 10.1590/S0080-62342012000100028

5. Bollela VR, Senger MH, Tourinho FSV, Amara E. Aprendizagem baseada em equipes: da teoria à prática. Medicina (Ribeirão Preto). 2014;47(3):293-300. doi: 10.11606/issn.2176-7262.v47i3p293-300

6. Hartz AM, Schlatter GV. A construção do trabalho de conclusão do curso por meio da metodologia ativa Team-Based Learning. Adm Ens Pesqui. 2016;17(1):73-109. doi: 10.13058/raep.2016.v17n1.274

7. Honda K, Chirelli MQ. Residência multiprofissional em saúde: formação com metodologias ativas de ensino-aprendizagem desenvolvimento curricular e didática [Internet]. In.: Atas do 4 Congresso Ibero-Americano em Investigação Qualitativa 2015 (CIAIQ 2015), 2015 Aug 5-7. Aracaju: CIAIQ; 2015 [cited 2018 Jan 10]. Available from: https://proceedings.ciaiq.org/index.php/ciaiq2015/article/view/292

8. Roh YS, Lee SJ, Mennenga H. Factors influencing learner satisfaction with team-based learning among nursing students. Nurs Health Sci. 2014;16(4):490-7. doi: 10.1111/nhs.12118

9. Krug RR, Vieira MSM, Maciel MVA, Erdmann TR, Vieira FCF, Koch MC et al. O “bê-á-bá" da aprendizagem baseada em equipe. Rev Bras Educ Med. 2016;40(4):602-20. doi: 10.1590/1981-52712015v40n4e00452015

10. Oliveira KRE, Braga EM. The development of communication skills and the teacher's performance in the nursing student's perspective. Rev Esc Enferm USP. 2016;50(n.esp): 032-038. doi: 10.1590/S0080-623420160000300005

11. Girondi JBR, Bollela VR, Tourinho F, Amante LN, Nascimento KC, Knihs NS, et al. Team-based learning in the teaching of perioperative care in undergraduate nursing. Int J Nurs Didactics. 2017;7:76-80. doi: 10.15520/ijnd.2017.vol7.iss4.217

12. Girondi JBR, Tourinho F, Ropelato-Fernandez DL, Bollela VR. Aprendizagem baseada em equipes (team-based learning-tbl) no ensino em enfermagem perioperatória. In: Knihs NS, Girondi JBR, Nascimento KC, Bellaguarda MLR, Sebold LF, Alvarez AG, Amante LN, organizadores. Metodologias Ativas no Ensino do cuidado de Enfermagem Perioperatória. Curitiba: Editora CRV; 2017, p. 52-64.

13. Park HR, Kim CJ, Park JW, Park E. Effects of team-based learning on perceived teamwork and academic performance in a health assessment subject. Collegian. 2015;22(3):299-305. doi: 10.1016/j.colegn.2014.05.001

14. Kim HR, Song Y, Lindquist R, Kang HY. Effects of team-based learning on problem-solving, knowledge and clinical performance of Korean nursing students. Nurs Educ Today. 2016;38:115-8. doi: 10.1016/j.nedt.2015.12.003

15. Kang KA, Kim SJ, Oh J, Kim S, Lee MN. Effectiveness of simulation with team-based learning in newborn nursing care. Nurs Health Sci. 2016;18(2):262-9. doi: 10.1111/nhs.12245

16. Barbiero AJC, Honorato AA, Vieira CF, Silva GTG, Ferreira IM, Barreiros LL, et al. Percepção dos acadêmicos de medicina sobre a metodologia de aprendizagem baseada em equipes na disciplina de farmacologia. Rev Cient Fagoc Saúde. 2017;2:43-9. Available from: https://revista. fagoc.br/index.php/saude/article/view/319

17. Guerra CJO, Teixeira AJC. The impacts of adopting active methods in the performance of accounting students at a higher education institution in the state of Minas Gerais. REPeC - Rev Educ Pesqui Contab. 2016;10(4):380-97. doi: 10.17524/repec.v10i4.1437

18. Marini, DC. Avaliação da experiência de estudantes de farmácia no componente curricular de farmacologia com a utilização da metodologia de aprendizagem baseada em tarefas [Internet]. FOCO. 2013 [cited 2018 Jan 10];4(5):89-110. Available from: http://www. revistafoco.inf.br/index.php/FocoFimi/article/download/34/38

19. Silva Junior GB, Medeiros MAS, Oliveira JGR, Catrib AMF, Jardim MHAG. Team-Based Learning: Successful Experience in a Public Health Graduate Program. Rev Bras Educ Med, 2017;41(3):397-401. doi: 10.1590/1981-52712015v41n3RB20160081

20. Ministério da Saúde (BR), Agência Nacional de Vigilância Sanitária (ANVISA), Organização Pan-Americana da Saúde (OPAS). Segundo desafio global para a segurança do paciente. Cirurgias seguras salvam vidas [Internet]. Brasília: Ministério da Saúde, OPAS, ANVISA; 2009 [cited 2018 Jan 10]. Available from: http://bvsms.saude.gov.br/bvs/publicacoes/seguranca_paciente_cirurgias_seguras_salvam_vidas.pdf

21. Swanson E, McCulley LV, Osman DJ, Lewis NS, Solis M. The effect of team-based learning on content knowledge: a meta-analysis. Active 
Team-based learning: a randomized clinical trial in undergraduate nursing Sakamoto SR, Dell'Acqua MCQ, Abbade LPF, Caldeira SM, Fusco SFB, Avila MAG.

Learn High Educ. 2017;0(0):1-12. doi: 10.1177/1469787417731201

22. Moher D, Schulz KF, Altman DG. The CONSORT Statement: revised recommendations for improving the quality of reports of parallel-group randomized trials. Lancet. 2001;357(9263):1191-4. doi: 10.1016/S0140-6736(00)04337-3

23. Currey J, Eustace P, Oldland E, Glanville D, Story I. Developing professional attributes in critical care nurses using team-based learning. Nurse Educ Pract. 2015;15(3):232-8. doi: 10.1016/j.nepr.2015.01.011

24. Huitt TW, Killins A, Brooks WS. Team-based learning in the gross anatomy laboratory improves academic performance and students' attitudes toward teamwork. Anat Sci Educ. 2014;8(2):95-103. doi: 10.1002/ase.1460

25. Cheng CY Liou SR, Hsu TH, Pan MY, Liu HC, Chang CH. Preparing nursing students to be competent for future professional practice: applying the team-based learning-teaching strategy. J Prof Nurs. 2014;30(4):347-56. doi: 10.1016/j.profnurs.2013.11.005

26. Mesquita SKC, Meneses RMV, Ramos DKR. Metodologias ativas de ensino/ aprendizagem: dificuldades de docentes de um curso de enfermagem. Trab Educ Saúde. 2016;14(2):473-86. doi: 10.1590/1981-7746-sip00114 